\title{
Establishment of callus culture of Melientha suavis Pierre
}

\author{
Duangporn Premjet ${ }^{1}$, Abraham K. Obeng ${ }^{2}$, and Siripong Premjet ${ }^{1,3^{*}}$
}

${ }^{1}$ Naresuan University, Faculty of Agriculture, Natural Resources and Environment, Center of Excellence in Research for Agricultural Biotechnology, Muang, Phitsanulok, 65000, Thailand.

${ }^{2}$ University for Development Studies, Faculty of Agriculture, Department of Biotechnology, P.O. Box TL 1882, Tamale, Ghana.

${ }^{3}$ Naresuan University, Faculty of Science, Department of Biology, Muang, Phitsanulok 65000, Thailand. 'Corresponding author (siripongp@nu.ac.th).

Received: 6 April 2020; Accepted: 29 May 2020; doi:10.4067/S0718-58392020000300459

\begin{abstract}
Melientha sauvis Pierre is an edible wild tree in Thailand. Local communities in Thailand harvest new shoot of the plant by burning the forest to stimulate it, a process that destroys the forest. This study was aimed at developing a methodology for callus culture production of $M$. suavis. Callus was induced from leaf, young stem, and shoot tip of M. suavis on Murashige and Skoog (MS) basal medium supplemented with various formulations of 2,4-dichlorophenoxyacetic acid (2,4-D) and 6-benzylaminopurine (6-BA). Callus produced from young stem explants appeared faster (14 d). Maximum callus growth (40\%) and fresh weight (5.56 g) were observed in young stem explant cultured on MS medium containing $2 \mathrm{mg} \mathrm{L}^{-1}$ 2,4-D. The findings of this work contribute to large scale micropropagation or bioactive compound production in M. suavis.
\end{abstract}

Key words: 6-Benzylaminopurine, callus cultures, 2,4-dichlorophenoxyacetic acid, pak wan pa.

\section{INTRODUCTION}

Melientha suavis Pierre is a wild plant species native to Southeast Asia (Le et al., 2018). It is a deciduous plant commonly found in the Northern parts of Thailand under the local name pak wan pa (Figure 1a and 1b) (Hempattarasuwan and Duangmal, 2015). The blossoming flowers and young leaves of this plant species are cooked and eaten as vegetables by local Thai communities (Prathepha, 2000). Young and ripe fruits are also boiled and seeds fried as food (Pignone and Hammer, 2016).

In Thailand, M. suavis is collected from the forest by some local communities once a year, from June to July. They burn the forest to stimulate new shoots of the plant, a process that leads to deforestation. Other communities also cultivate the plant mainly from young seedlings obtained from commercial nurseries. Cultivation of M. suavis in Thailand is often carried out by intercropping in orchard farms (Pignone and Hammer, 2016). However, long seedling period restricts rapid commercial cultivation of M. suavis (Amprayn et al., 2013). Tissue culture techniques can be used to eliminate these constraints (Al-Khayri, 2011).

Plant tissue culture techniques are very important for rapid and mass propagation of plants (Castro et al., 2016). Establishing a tissue culture technique for M. suavis is therefore very critical for its commercial cultivation (Pacheco et al., 2012). Plant growth regulators are very essential for in vitro propagation (Libin et al., 2012). The concentration and type of these growth regulators are very crucial for the in vitro culture system (Karalija and Paric, 2011). Auxins and cytokinins are mostly used for callus induction because of their ability to stimulate cell division and elongation (Castro et al., 2016). The auxin 2,4-dichlorophenoxyacetic acid (2,4-D) and cytokinin 6-benzylaminopurine (6-BA) have been extensively used individually or in combination, at various formulations, to induce callus of various plant species (AlKhayri, 2011; Karalija and Paric, 2011; Saensouk, 2011; Bhagya and Chandrashekar, 2013; Castro et al., 2016).

In this study, the suitable explant and optimum concentrations of the auxin 2,4-D and cytokinin 6-BA for callus induction of Melientha suavis Pierre were determined. 
Figure 1. Melientha suavis mature tree with fruits (a) and edible young shoots (b).

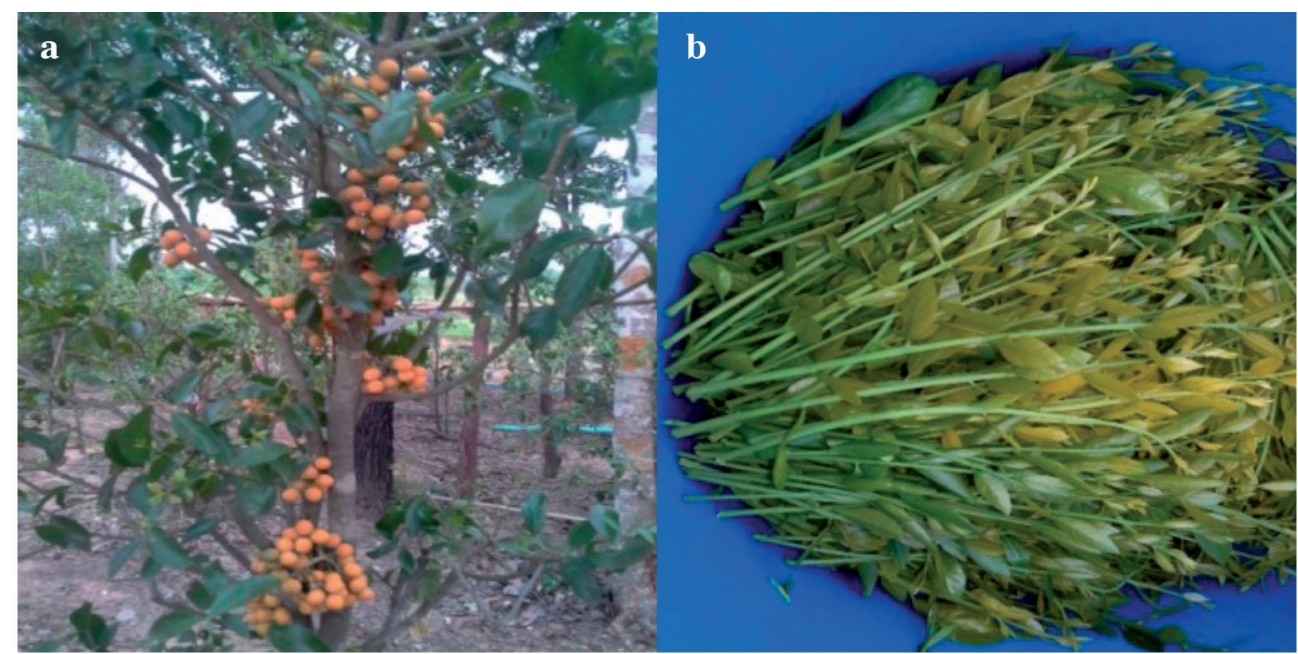

\section{MATERIALS AND METHODS}

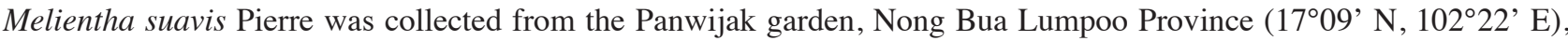
Nong Bua Lumpoo Province, Thailand, from June to July 2016 and 2017. The botanical identity was confirmed by Herbarium, Department of Biology, Naresuan University. The plant was deposited at the Herbarium (herbarium deposit voucher 004661), Department of Biology, Naresuan University and Laboratory for further reference.

The stem, leaf, and shoot tip explants of $M$. suavis were each put into a separate flask. The explants were cleaned with $0.5 \mathrm{~mL}$ surfactant composed of sodium lauryl ether sulfate $(7.2 \%, \mathrm{w} / \mathrm{w})$ and linear alkylbenzene sulfonate potassium salt $(10.0 \%, \mathrm{w} / \mathrm{w})$ and washed with running tap water. The surface was then disinfected with sodium hypochlorite $(0 \%, 10 \%$, $15 \%$ and $20 \%$ ) for $8 \mathrm{~min}$, after which they were washed well with sterile distilled water for $10 \mathrm{~min}$ trice. All explants were cut into $1 \times 1 \mathrm{~cm}$ pieces. Each explant piece was then place in a $120 \mathrm{~mL}$ glass bottle containing Murashige and Skoog (MS) basal medium with vitamins $(3 \%, \mathrm{w} / \mathrm{v})$, sucrose $\left(30 \mathrm{~g} \mathrm{~L}^{-1}\right)$, agar $(0.8 \%, \mathrm{w} / \mathrm{v})$, and supplemented with $0.0,0.1,0.2$, $0.3,0.4$, and $0.5 \mathrm{mg} \mathrm{L}^{-1}$ 6-benzylaminopurine (6-BA) alone or with $0,1,2,3,4$, and $5 \mathrm{mg} \mathrm{L}^{-1}$ 2,4-dichlorophenoxyacetic acid (2,4-D). The $\mathrm{pH}$ was then adjusted to 5.6 before autoclaving.

The cultured explants were transferred to a growth chamber and maintained at $24 \pm 2{ }^{\circ} \mathrm{C}$ under $12: 12 \mathrm{~h}$ photoperiod illuminated by warm white LED bulb (18 W, bioBULB, Bangkok, Thailand) with intensity of $40 \mu \mathrm{mol} \mathrm{m} \mathrm{m}^{-2} \mathrm{~s}^{-1}$ and 85 $\pm 5 \%$ relative humidity (Muñoz et al., 2019). Survival rate and the number of callus formation of the cultured explants were evaluated for 8 wk. Sub-culturing was conducted by transferring the callus to fresh MS medium containing the same type of growth regulators as before. The third sub-cultured callus was then collected and the fresh weight (g) determined. Aspect and color of callus were also evaluated. The scale of visual appreciation used included friable (soft and loose textured) and compact (dense textured).

The experiments were conducted according to the complete randomized design (CRD). Callus cultures were evaluated for up to $56 \mathrm{~d}$. The data were subjected to one-way ANOVA and Tukey test for separation media at $\mathrm{p}<0.05$, using SPSS version 16.0 (SPSS Inc., Chicago, Illinois, USA). The data presented are the average of 10 replicates and their corresponding standard deviations.

\section{RESULTS}

Young stem, leaves, and shoot tips were used as explants to start callus initiation in the current study. All explants were surface sterilized in $0 \%, 10 \%, 15 \%$, and $20 \%$ sodium hypochlorite for 8 min prior to culturing. Explants surface sterilized with $15 \%$ sodium hypochlorite had significantly $(\mathrm{p}<0.05)$ highest survival rate (Table 1$)$. The survival rate of leaf, young 
stem and shoot tips sterilized with $15 \%$ sodium hypochlorite were $60 \%, 80 \%$ and $50 \%$, respectively. Sterilization with sodium hypochlorite concentrations above and below $15 \%$ resulted in a survival rate below $50 \%$. The sodium hypochlorite concentration of $15 \%$ was therefore selected and used for surface sterilization of all explants in subsequent studies.

Effect of 6-BA at different concentrations $\left(0.0,0.1,0.2,0.3,0.4\right.$, and $\left.0.5 \mathrm{mg} \mathrm{L}^{-1}\right)$ on callus formation rate of the leaf, young stem, and shoot tip explants were recorded weekly for $8 \mathrm{wk}$ in vitro (Tables 2, 3,4). The earliest callus clump from young stem appeared after $21 \mathrm{~d}$ of culturing (Table 2). Maximum callus formation in young stem explants (30\%) was observed with the application of $0.3 \mathrm{mg} \mathrm{L}^{-1} 6-\mathrm{BA}$. Callus formation in young stem explants with the application of $0.3 \mathrm{mg} \mathrm{L}^{-1} 6-\mathrm{BA}$ increased to $30 \%$ after $21 \mathrm{~d}$, beyond which there was no increase. Callus formation in leaf explants however delayed till $35 \mathrm{~d}$ after culturing. Leaf explant recorded very low callus formation rate (10\%) at the various concentrations of 6-BA (Table 3). Shoot tip formed callus only on MS medium supplemented with $0.1 \mathrm{mg} \mathrm{L}^{-1}$ 6-BA (Table 4). Callus formation (10\%) in shoot tip was observed after $21 \mathrm{~d}$ of culturing. This was maintained up to $35 \mathrm{~d}$, beyond which the callus started browning and died. Young stem explant cultured in MS medium with $0.3 \mathrm{mg} \mathrm{L}^{-1}$ 6-BA was identified as appropriate for inducing callus in M. suavis.

Table 1. Effect of sodium hypochlorite concentrations on the survival rate of Melientha suavis explants.

\begin{tabular}{cccc}
\hline & \multicolumn{3}{c}{ Survival rate } \\
\cline { 2 - 4 } Sodium hypochlorite & Leaves & Young stem & Shoot tips \\
\cline { 2 - 4 }$\%$ & $10 \pm 2.0 \mathrm{c}$ & $10 \pm 1.3 \mathrm{c}$ & $10 \pm 1.7 \mathrm{c}$ \\
0 & $40 \pm 3.5 \mathrm{~b}$ & $40 \pm 2.6 \mathrm{~b}$ & $30 \pm 3.0 \mathrm{~b}$ \\
10 & $60 \pm 3.6 \mathrm{a}$ & $80 \pm 4.6 \mathrm{a}$ & $50 \pm 5.3 \mathrm{a}$ \\
15 & $30 \pm 5.6 \mathrm{~b}$ & $40 \pm 4.0 \mathrm{~b}$ & $30 \pm 1.5 \mathrm{~b}$ \\
\hline
\end{tabular}

Data are presented as mean $\pm \mathrm{SD}$. Means with different letters in the same column are different according Tukey test $(\mathrm{p}<0.05)$.

Table 2. Effect of 6-benzylaminopurine (6-BA) and young stem explants on Melientha suavis callus formation.

\begin{tabular}{|c|c|c|c|c|c|c|c|c|}
\hline \multirow[b]{2}{*}{$6-\mathrm{BA}$} & \multicolumn{8}{|c|}{ Rate of callus formation } \\
\hline & $7 d$ & $14 \mathrm{~d}$ & $21 \mathrm{~d}$ & $28 \mathrm{~d}$ & $35 \mathrm{~d}$ & $42 \mathrm{~d}$ & $49 \mathrm{~d}$ & $56 \mathrm{~d}$ \\
\hline $\mathrm{mg} \mathrm{L}^{-1}$ & & & & & $-\%$ & & & \\
\hline Control & 0 & 0 & 0 & 0 & 0 & 0 & 0 & 0 \\
\hline 0.1 & 0 & 0 & $20 \pm 3.0 \mathrm{~b}$ & $20 \pm 3.0 \mathrm{~b}$ & $20 \pm 3.0 \mathrm{~b}$ & $20 \pm 3.0 \mathrm{~b}$ & $20 \pm 3.0 \mathrm{~b}$ & $20 \pm 3.0 \mathrm{~b}$ \\
\hline 0.2 & 0 & 0 & 0 & 0 & 0 & 0 & 0 & 0 \\
\hline 0.3 & 0 & 0 & $30 \pm 3.6 \mathrm{a}$ & $30 \pm 3.6 \mathrm{a}$ & $30 \pm 3.6 \mathrm{a}$ & $30 \pm 3.6 \mathrm{a}$ & $30 \pm 3.6 a$ & $30 \pm 3.6 a$ \\
\hline 0.4 & 0 & 0 & $10 \pm 1.7 \mathrm{c}$ & $10 \pm 1.7 \mathrm{c}$ & $10 \pm 1.7 \mathrm{c}$ & $10 \pm 1.7 \mathrm{c}$ & $10 \pm 1.7 \mathrm{c}$ & $10 \pm 1.7 \mathrm{c}$ \\
\hline 0.5 & 0 & 0 & 0 & 0 & 0 & 0 & 0 & 0 \\
\hline
\end{tabular}

Data are presented as mean \pm SD. Means with different letters in the same column are different according Tukey test $(\mathrm{p}<0.05) .0$ represents no callus formation.

Table 3. Effect of 6-benzylaminopurine (6-BA) and leaf explants on Melientha suavis callus formation.

\begin{tabular}{|c|c|c|c|c|c|c|c|c|}
\hline \multirow[b]{2}{*}{$6-\mathrm{BA}$} & \multicolumn{8}{|c|}{ Rate of callus formation } \\
\hline & $7 \mathrm{~d}$ & $14 \mathrm{~d}$ & $21 \mathrm{~d}$ & $28 \mathrm{~d}$ & $35 \mathrm{~d}$ & $42 \mathrm{~d}$ & $49 \mathrm{~d}$ & $56 \mathrm{~d}$ \\
\hline $\mathrm{mg} \mathrm{L}^{-1}$ & & & & & $\%$ & & & \\
\hline Control & 0 & 0 & 0 & 0 & 0 & 0 & 0 & 0 \\
\hline 0.1 & 0 & 0 & 0 & 0 & $10 \pm 1.0$ & $10 \pm 1.0$ & $10 \pm 1.0 \mathrm{a}$ & $10 \pm 1.0 \mathrm{a}$ \\
\hline 0.2 & 0 & 0 & 0 & 0 & 0 & 0 & $10 \pm 1.8 \mathrm{a}$ & $10 \pm 1.8 \mathrm{a}$ \\
\hline 0.3 & 0 & 0 & 0 & 0 & 0 & 0 & $10 \pm 2.6 \mathrm{a}$ & $10 \pm 2.6 a$ \\
\hline 0.4 & 0 & 0 & 0 & 0 & 0 & 0 & $10 \pm 2.0 \mathrm{a}$ & $10 \pm 2.0 \mathrm{a}$ \\
\hline 0.5 & 0 & 0 & 0 & 0 & 0 & 0 & $10 \pm 1.7 \mathrm{a}$ & $10 \pm 1.7 \mathrm{a}$ \\
\hline
\end{tabular}

Data are presented as mean \pm SD. Means with different letters in the same column are different according Tukey test $(\mathrm{p}<0.05) .0$ represents no callus formation. 
Table 4. Effect of 6-benzylaminopurine (6-BA) and shoot tips explants on Melientha suavis callus formation.

\begin{tabular}{|c|c|c|c|c|c|c|c|c|}
\hline \multirow[b]{2}{*}{$6-\mathrm{BA}$} & \multicolumn{8}{|c|}{ Rate of callus formation } \\
\hline & $7 \mathrm{~d}$ & $14 \mathrm{~d}$ & $21 \mathrm{~d}$ & $28 \mathrm{~d}$ & $35 \mathrm{~d}$ & $42 \mathrm{~d}$ & $49 \mathrm{~d}$ & $56 \mathrm{~d}$ \\
\hline $\mathrm{mg} \mathrm{L}^{-1}$ & & & & & $-\%$ & & & \\
\hline Control & 0 & 0 & 0 & 0 & 0 & 0 & 0 & 0 \\
\hline 0.1 & 0 & 0 & $10 \pm 1.5$ & $10 \pm 1.5$ & $10 \pm 1.5$ & 0 & 0 & 0 \\
\hline 0.2 & 0 & 0 & 0 & 0 & 0 & 0 & 0 & 0 \\
\hline 0.3 & 0 & 0 & 0 & 0 & 0 & 0 & 0 & 0 \\
\hline 0.4 & 0 & 0 & 0 & 0 & 0 & 0 & 0 & 0 \\
\hline 0.5 & 0 & 0 & 0 & 0 & 0 & 0 & 0 & 0 \\
\hline
\end{tabular}

Data are presented as mean \pm SD. 0 represents no callus formation.

The addition of 2,4-D to the MS medium affected the rate of callus formation from young stem explants. Callus formation from young stem explants on MS medium containing 2,4-D was observed after $14 \mathrm{~d}$ (Table 5), which was faster when compared to that of young stem explants on MS medium containing 6-BA (Table 2). The highest callus formation percentage (40\%) was achieved when $2 \mathrm{mg} \mathrm{L}^{-1}$ 2,4-D was added to the MS medium. The fresh callus of young stem cultured on MS medium containing $2 \mathrm{mg} \mathrm{L}^{-1}$ 2,4-D and MS medium containing $0.3 \mathrm{mg} \mathrm{L}^{-1} 6$-BA were analyzed after sub-culturing twice (Table 6). Fresh callus obtained from MS medium containing $0.3 \mathrm{mg} \mathrm{L}^{-1}$ 6-BA was pale green with an average weight of $3.51 \mathrm{~g}$ per bottle (Figure 2). However, fresh callus on MS medium containing $2 \mathrm{mg} \mathrm{L}^{-1}$ 2,4-D was yellow with an average weight of $5.56 \mathrm{~g}$ per bottle (Figure 3).

\section{DISCUSSION}

Melientha suavis is a very important food plant for the local communities in Northern Thailand (Hempattarasuwan and Duangmal, 2015). They are commonly sold in local markets as vegetables (Prathepha, 2000). Phytochemical compounds have also been reported for M. suavis (Charoenchai et al., 2015). A micro-propagation system using explants from leaves, young stem, and shoot tips was evaluated in this study. Contamination is a major obstacle during in vitro propagation of

Table 5. Effect of 2,4-dichlorophenoxyacetic acid (2,4-D) on callus formation of Melientha suavis young stem explants.

\begin{tabular}{|c|c|c|c|c|c|c|c|c|}
\hline \multirow[b]{2}{*}{ 2,4-D } & \multicolumn{8}{|c|}{ Rate of callus formation } \\
\hline & $7 d$ & $14 \mathrm{~d}$ & $21 \mathrm{~d}$ & $28 \mathrm{~d}$ & $35 \mathrm{~d}$ & $42 \mathrm{~d}$ & $49 \mathrm{~d}$ & $56 \mathrm{~d}$ \\
\hline $\mathrm{mg} \mathrm{L}^{-1}$ & & & & 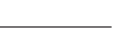 & $\%$ & & & 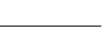 \\
\hline Control & 0 & 0 & 0 & 0 & 0 & 0 & 0 & 0 \\
\hline 1 & 0 & 0 & $10 \pm 1.3 b$ & $10 \pm 1.3 b$ & $10 \pm 1.0 \mathrm{~b}$ & 0 & 0 & 0 \\
\hline 2 & 0 & $20 \pm 2.6$ & $20 \pm 2.6 a$ & $20 \pm 2.6 a$ & $20 \pm 2.6 a$ & $40 \pm 3.2$ & $40 \pm 3.2$ & $40 \pm 3.2$ \\
\hline 3 & 0 & 0 & 0 & 0 & 0 & 0 & 0 & 0 \\
\hline 4 & 0 & 0 & 0 & 0 & 0 & 0 & 0 & 0 \\
\hline 5 & 0 & 0 & 0 & 0 & 0 & 0 & 0 & 0 \\
\hline
\end{tabular}

Data are presented as mean \pm SD. Means with different letters in the same column are different according Tukey test $(\mathrm{p}<0.05) .0$ represents no callus formation.

Table 6. Effect of 6-benzylaminopurine (6-BA) and 2,4-dichlorophenoxyacetic acid (2,4-D) on fresh callus weight of Melientha suavis young stem explants.

\begin{tabular}{lcc}
\hline 6-BA & $2,4-\mathrm{D}$ & Fresh weight \\
\hline $\mathrm{mg} \mathrm{L}^{-1}$ & $\mathrm{mg} \mathrm{L}^{-1}$ & $\mathrm{~g} \mathrm{bottle}^{-1}$ \\
0.0 & 0.0 & 0.0 \\
0.3 & 0.0 & $3.51 \pm 0.16 \mathrm{~b}$ \\
0.0 & 2.0 & $5.56 \pm 0.15 \mathrm{a}$ \\
\hline
\end{tabular}

Data are presented as mean $\pm \mathrm{SD}$. Means with different letters in the same column are different according Tukey test $(\mathrm{p}<0.05)$. 
Figure 2. Compact, friable, cream, pale green callus cultures of Melientha suavis on MS medium supplemented with $0.3 \mathrm{mg} \mathrm{L}^{-1}$ 6-benzylaminopurine $($ Bar $=1 \mathrm{~cm})$.
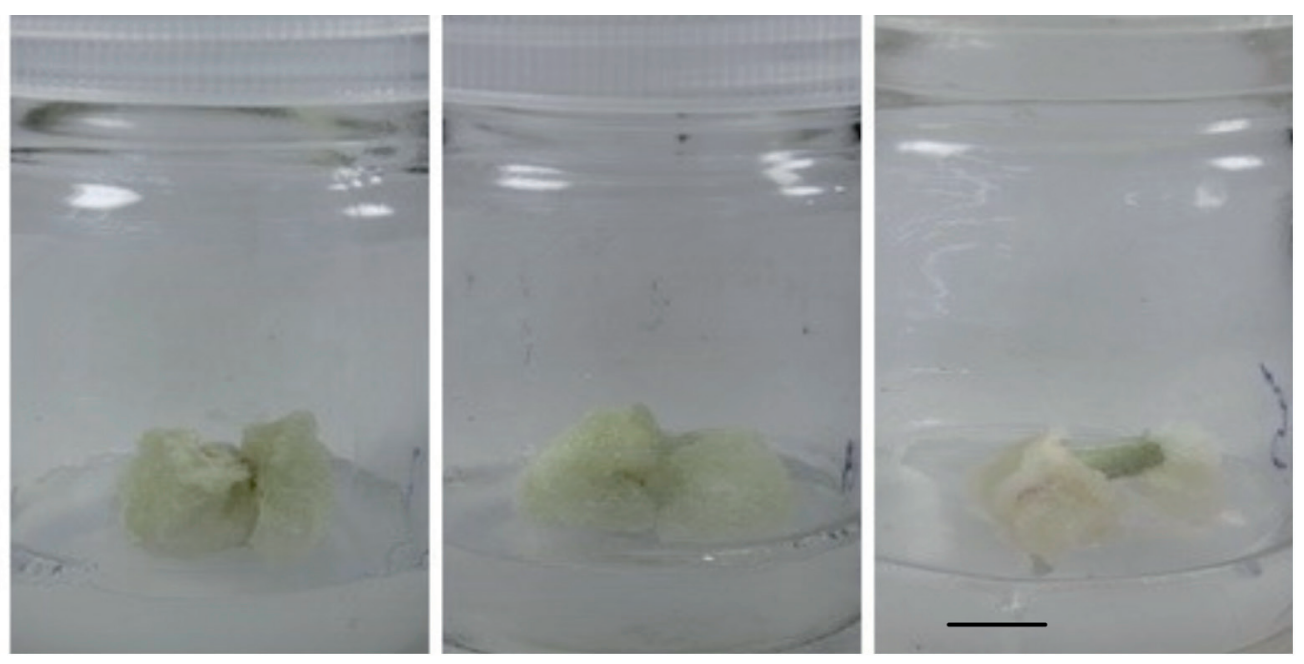

Figure 3. Compact, friable, yellow, light green callus cultures of Melientha suavis on MS medium supplemented with $2 \mathrm{mg} \mathrm{L}^{-1}$ 2,4-dichlorophenoxyacetic acid $(\mathrm{Bar}=1 \mathrm{~cm})$.
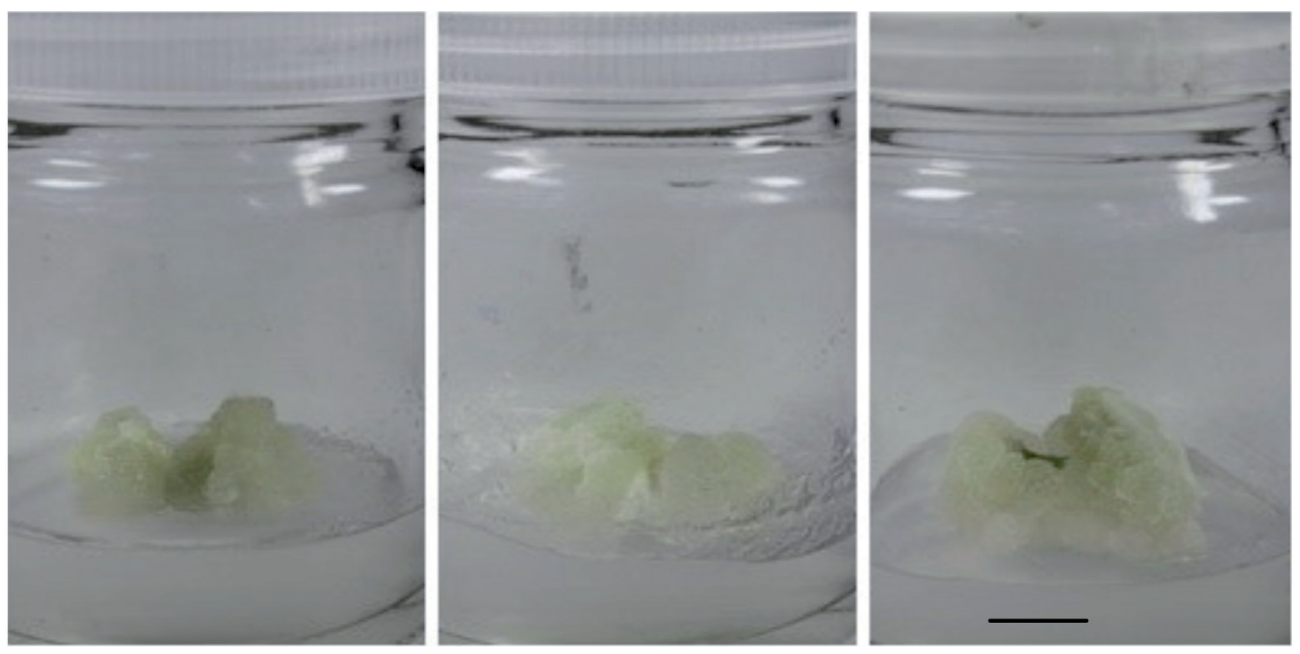

plants. Surface sterilization is very important in minimizing contamination in the micro-propagation system (Shen et al., 2011). The concentration and type of chemical compound used for surface sterilization may be a hindrance to the in vitro propagation method. Establishing a unique sterilization technique for a particular micro-propagation system is therefore important for its success. In the current study, surface sterilization using $15 \%$ sodium hypochlorite was identified as been suitable for in vitro propagation of M. suavis (Table 1). Sodium hypochlorite concentrations below or above $15 \%$ resulted in the low survival rate of explants.

In vitro plant propagation is normally carried out by culturing different plant parts obtained from the whole plant on an appropriate nutrient medium. The choice of a suitable explant, among other factors, is very important for the success of in vitro plant propagation (Manawadu et al., 2016). Initiation of callus cultures of $M$. suavis was successfully carried out by using the young stem as starting explant. Leaf and shoot tip explants did not give good response to in vitro conditions which were set up in this study. Numerous studies have reported successful in vitro propagation with stem explant. Bhagya and Chandrashekar (2013) successfully induced callus from young stem explants of Cyclea peltata on MS medium containing 6-benzyl amino purine (BAP) + naphthaleneacetic acid (NAA) 
and $\mathrm{BAP}+$ indole acetic acid (IAA) at concentrations of $2+3 \mathrm{mg} \mathrm{L}^{-1}$ and $0.5+0.1 \mathrm{mg} \mathrm{L}^{-1}$, respectively. Stem explants of Taxus baccata $\mathrm{L}$. produced better callus on B5 medium containing $0.5 \mathrm{mg} \mathrm{L}^{-1} \mathrm{NAA}, 20 \mathrm{~g} \mathrm{~L}^{-1}$ sucrose, 0.1 $\mathrm{mM}$ gluthatione, $500 \mathrm{mg} \mathrm{L}^{-1}$ casein, $2 \mathrm{mg} \mathrm{L}^{-1}$ 2,4-D, $0.4 \mathrm{mg} \mathrm{L}^{-1}$ kinetin, and $8 \mathrm{~g} \mathrm{~L}^{-1}$ agar when compared to leaf explant (Ghafoori et al., 2012).

Plant growth regulators are very essential in the growth and development of plants in vitro. Auxins and cytokinins are normally used for callus induction because of their ability to stimulate cell division and elongation (Castro et al., 2016). A suitable concentration or mixture of these growth regulators must be established for each plant species (Castro et al., 2016). The auxin 2,4-D was found to be more appropriate for callus induction from the young stem of M. suavis when compared to the cytokinin 6-BA (Table 5). Supplementing MS medium with $2 \mathrm{mg} \mathrm{L}^{-1}$ 2,4-D was more effective when compared to the other concentrations studied. Saensouk (2011) reported that supplementing MS medium with $2 \mathrm{mg} \mathrm{L}^{-1}$ 2,4-D was more suitable for inducing callus from young leaves of Cornukaempferia aurantiflora. Callus induction from rice (Oryza sativa L.) seeds was highest (97\%) on MS medium containing $2 \mathrm{mg} \mathrm{L}^{-1}$ 2,4-D (Libin et al., 2012). The findings of this study are very useful for further research on in vitro propagation of $M$. suavis for large scale production, gene transformation or production of bioactive compounds.

\section{CONCLUSIONS}

The study has demonstrated that young stem explant from Melientha suavis is more appropriate for callus induction. The auxin 2,4-D at $2 \mathrm{mg} \mathrm{L}^{-1}$ in the MS basal medium with vitamins (3\%, w/v), sucrose, and agar $(0.8 \%$, w/v) is more appropriate for callus induction. Surface sterilization with $15 \%$ sodium hypochlorite was found to be very essential for a successful callus formation.

\section{ACKNOWLEDGEMENTS}

The research project (R2559B128) was funded by Naresuan University under the projects initiated by H.R.H. Maha Chakri Sirindhorn in the fiscal year 2016.

\section{REFERENCES}

Al-Khayri, J.M. 2011. Influence of yeast extract and casein hydrolysate on callus multiplication and somatic embryogenesis of date palm (Phoenix dactylifera L.) Scientia Horticulturae 130:531-535. doi:10.1016/j.scienta.2011.07.024.

Amprayn, K., Keawduang, M., Tangkoonboribun, R., and Tanpanich, S. 2013. Growth enhancement of Pak Wanpa (Melientha suavis Pierre) by inoculating with plant growth-promoting microorganisms and incorporated sowing with Agasta (Sesbania grandiflora (L.)) Poir. Abstract O27. In Proceedings of the 51 $1^{\text {st }}$ Kasetsart University Annual Conference, Bangkok, Thailand. 5-7 February. Kasetsart University Annual Conference, Bangkok, Thailand.

Bhagya, N., and Chandrashekar, K.R. 2013. Effect of growth regulators on callus induction from Cyclea peltata (Lam.) Hook. F. Thoms. Asian Journal of Pharmaceutical and Clinical Research 6:85-88.

Castro, A.H.F., Braga, K.D.Q., Sousa, F.M.D., Coimbra, M.C., and Chagas, R.C.R. 2016. Callus induction and bioactive phenolic compounds production from Byrsonima verbascifolia (L.) DC. (Malpighiaceae). Revista Ciência Agronômica 47:143-151. doi:10.5935/1806-6690.20160017.

Charoenchai, L., Settharaksa, S., Madaka, F., and Sueree, L. 2015. Evaluation of the antioxidant activities, total phenolic and flavonoid contents of Melientha suavis Pierre. Bulletin of Health, Science and Technology 12:29-37.

Ghafoori, R., Bernard, F., Abolmaali, S., and Mousavi, A. 2012. Improved effect of glutathione on the induction and growth of Taxus baccata L. callus. Annals of Biological Research 3:1726-1730.

Hempattarasuwan, P., and Duangmal, K. 2015. Effect of growing location, cooking method and brine salting on Melientha suavis Pierre (Pak Wann Paa) qualities. Acta Horticulturae 1088:587-590. doi.org/10.17660/ActaHortic.2015.1088.108.

Karalija, E., and Paric, A. 2011. The effect of BA and IBA on the secondary metabolite production by shoot culture of Thymus vulgaris L. Biologica Nyssana 2:29-35.

Le, C.T., Liu, B., Barrett, R.L., Lu, L.M., Wen, J., and Chen, Z.D. 2018. Phylogeny and a new tribal classification of Opiliaceae (Santalales) based on molecular and morphological evidence. Journal of Systematics and Evolution 56:56-66. doi:10.1111/jse.12295. 
Libin, A., King, P., Ong, K., Chubo, J., and Sipen, P. 2012. Callus induction and plant regeneration of Sarawak rice (Oryza sativa L.) variety Biris. African Journal of Agricultural Research 7:4260-4265. doi:10.5897/AJAR12. 587.

Manawadu, I., Dahanayake, N., Gamini, S., and Senanayake, N. 2016. Effects of different natural organic additives on in vitro shoot regeneration of Raphanus sativus L. var. Beeralu. Journal of Agricultural Science and Technology 4:219-223.

Muñoz, M., Díaz, O., Reinún, W., Winkler, A., and Quevedo, R. 2019. Slow growth in vitro culture for conservation of Chilotanum potato germplasm. Chilean Journal of Agricultural Research 79:26-35. doi:10.4067/S0718-58392019000100026.

Pacheco, G., Garcia, R., Lugato, D., Vianna, M., and Mansur, E. 2012. Plant regeneration, callus induction and establishment of cell suspension cultures of Passiflora alata Curtis. Scientia Horticulturae 144:42-47. doi.org/10.1016/j.scienta.2012.06.022.

Pignone, D., and Hammer, K. 2016. Parasitic angiosperms as cultivated plants? Genetic Resources and Crop Evolution 63:12731284. doi:10.1007/s10722-016-0416-X.

Prathepha, P. 2000. Detection of RAPD variation in a forest tree species, Melientha suavis Pierre (Opiliaceae) from Thailand. ScienceAsia 26:213-218.

Saensouk, P. 2011. Callus induction and plant regeneration from leaf explant of Cornukaempferia aurantiflora Mood \& Larsen. Pakistan Journal of Botany 43:2415-2418.

Shen, X., Gmitter, F.G., and Grosser, J.W. 2011. Immature embryo rescue and culture. p. 75-92. In Thorpe, T.A., and Yeung, E.C. (eds.) Plant embryo culture: Methods and protocols. Humana Press, Totowa, New Jersey, USA. 